\title{
Level of Satisfaction among Farmers Attending Kisan Mela
}

\author{
Jitendra Pratap ${ }^{1 *}$, Mohd. Ameer Khan ${ }^{1}$, Rajesh Mandil ${ }^{2}$, Vijay Singh $^{3}$ and V.P. Singh ${ }^{4}$ \\ ${ }^{1}$ Department of Veterinary and Animal Husbandry Extension Education, ${ }^{2}$ Department of \\ Pharmacology \& Toxicology, ${ }^{3}$ Department of Gynecology and Obstetrics, ${ }^{4}$ Departmenyt of \\ Livestock Products Technology COVAS, SVPUAT, Meerut, India
}

*Corresponding author

\section{A B S T R A C T}

\section{Keywords \\ Pesticide, insecticide, \\ Farmers, Scientist, Kisan Mela, Stall, Drinking water arrangement}

\section{Article Info}

Accepted:

04 October 2019

Available Online:

10 November 2019
The main purpose of organising such Kisan Mela is to create awareness among Kisan Mela visitors about new technologies developed by researchers primarily from the government agricultural and allied research centres, state agricultural universities and some private sector institutions. The present study was purposively conducted during Kisan Mela to know the satisfaction level of respondents regarding location of venue, orientation of stalls, arrangement for livestock, arrangement for animal exhibition, availability of quality seeds, information regarding new variety of crops, pesticide and insecticide and overall effect of Kisan Mela to the visitors. The level of satisfaction was calculated on three point continuum basis viz., most satisfied, satisfied and not satisfied with the score of 3,2 and 1 respectively. The total weighted mean score (TWMS) was calculated and ranking was done. The majority of respondents showed most satisfied in the area of investigation viz., location of venue, orientation of different stall, drinking water arrangement, staying facilities for livestock, arrangement of animal exhibition, availability of quality seeds, information regarding new strains of crops, information on pesticide and insecticide and overall effect of Kisan Mela. The majority of respondents said that they were not capable to pay for obtaining information regarding agriculture.

\section{Introduction}

India is agrarian country and most of the people dependent on the agriculture and allied sector. Agriculture is the backbone of the India and it contributes more than $15 \%$ in total GDP of the country. The growth of agricultural sector in not up to the mark despite the government efforts to accelerate this important sector. The information need of the farmers is changing day by day and the farmers access the information from various sources as per their need. Now a day there is a lot of the information sources are present but 
the farmers only rely on those sources which are credible and they use them informally. The research organization and government efforts to increase the production of agricultural and allied sectors by developing the newer technologies and other means which boost the income of the farmers. The government is making efforts to double the income of the farmers in 2022. The scientist, policy makers, extension workers and other private sector people developed a lot of literature in the area of agriculture which need to be transmitted to the farmers. The fast growth of the agriculture sector is only be achieved by transferring the new information from lab to land.

Dissemination of agricultural information and improved technology through the use of latest communication technology can play a great role in agricultural development (Patel et al., 1993). Kisan Mela is one of the method to aware and transfer the information to large number of farmers in a short duration. Kisan Mela and kisan goshthis (Farmer-scientist interactions) have been key activities of agriculture research institutes to spread awareness about the new technologies among farmers and to address their problems (Shirur 2014). Kisan Mela acts as platform for the farming community for awareness creation and adoption of new agro-techniques. These events help the line departments of agriculture and related sectors to deliver information about improved technologies to farmers. Scientific community showcasing and provide a wide range of choices of new techniques to farmers. These fairs help the farmers to enhance their knowledge on new schemes or programmes and it attract number of farmers, scientist, students, and extension workers from the KVK and the agriculture and allied departments (Tanusha and Chander, 2019). Despite of the new technologies in agricultural and allied sectors, farmers have to face the problem of proper channel media or resources to make them aware of current technologies within a period of time uses in agricultural practices.

There is a tremendous gap between knowledge production and knowledge utilization by the farmers (Sharma, 2014). Kisan Mela had various stalls on hybrid seeds, fertilizers, Tractors, Banking sector, Mineral Mixture, Medicine, different utensils used in dairying etc. Organizing Kisan Mela demand a lot of investment and hard work from the different people. The whole event is organized for visitors, so their satisfaction was prime concern for success of event and obtaining desired goal of creating awareness among the farmers. The present study was designed to know the level of satisfaction of the farmers who attended the Kisan Mela and to ascertain that farmers were really benefited to these events. Various requirements occupies so much of man's life span, that the satisfaction or dissatisfaction with it could affect in all walks of life. For the sake of examine the satisfaction level of respondents in the different areas viz., location of venue, orientation of different stall, drinking water arrangement, staying facilities for livestock, arrangement of animal exhibition, availability of quality seeds, information regarding new strains of crops, information regarding to pesticide and insecticide and overall effect of Kisan Mela etc., were selected. The satisfaction level of the respondents was calculated on three point continuum, total weighted mean score calculated and then ranking of different aspect done.

\section{Materials and Methods}

The study was conducted in Kisan Mela organized at Sardar Vallabhbhai Patel University of Agriculture and Technology (SVPUAT), Meerut district of Uttar Pradesh. A simple random sampling technique was used in the selection of respondents. The respondents were mostly farmers who visited 
Kisan Mela. The respondents were personally interviewed to know the satisfaction level of Kisan Mela visitors about different component of the event, with the help of pre-tested, semistructured interview schedule. There were 40 respondents were interviewed on each day so a total 120 Kisan Mela visitors (respondents) were interviewed in successive three day duration of Kisan Mela. The data was collected on three point continuum scale, namely, most satisfied (MS), satisfied (S) and not satisfied (NS) and the scoring system followed 3, 2, and 1 respectively. The total weighted mean score was calculated and then ranking was done on the basis of total weighted mean score. Further, total weighted mean scores were calculated for each aspect by adding up frequencies and multiplied with respective continuum scores and divided by maximum possible score obtained by that aspect assigned by all respondents. Total weighted mean score (TWMS) was calculated with the help of following formula-

TWMS $=$ freq of $\mathrm{MSx} 3+$ freq of $\mathrm{Sx} 2+$ freq of NSx1/ Maximum possible score given by all respondents to a particular indicator

Freq $=$ Frequency, $\mathrm{MS}=$ Most satisfied, $\mathrm{S}=$ Satisfied, NS $=$ Not satisfied

\section{Results and Discussion}

\section{Profile of the respondents}

Table 1 revealed that 32.5 per cent respondents were had education up to graduation and above, intermediate (28.3\%), junior high school (17.5\%), primary education $(15.0 \%)$ and 6.7 per cent respondents able to read and write only. There was no respondent found to be illiterate in the sample size of 120 . Education pattern of respondents showed that well educated persons were also involved in agriculture and allied sector. Education is the major tool to improve the production system and also helpful to disseminate technologies at faster rate among educated farmers. This study revealed that formal education already spread in pastoral society. Table 1 further revealed that 45.0 per cent respondents were engaged in agriculture and livestock rearing, as main occupation of livelihood. About 36.7 per cent respondents were engaged in agriculture, livestock as well as some sort of business for their earning, 12.5 per cent respondents had livestock rearing as an occupation. Only 5.8 per cent respondents performed daily wages work along with livestock rearing. The study indicated that modern rural society persons were involved in diversified work related to agriculture and allied sectors. This type of occupation pattern indicated that extension and advisory services provided by public sector should be intense as well as diversified. Table 1 further indicated that the majority (60.0\%) respondents come to visit Kisan Mela by own resources, this is an important indication of information seeking behaviour of respondent. 36.7 per cent respondents were visited Kisan Mela with the help of KVK which is considered as an innovation extension education institution (Dubey et al., 2008). It is well proof fact that KVK is capable to bring about significant changes in the Socio-economic status of different categories of farmers by exposing to such kind of visit and very few (3.3\%) respondents visited Mela with the help of different NGOs.

Table 1 further showed that the majority (60.8\%) respondents were visited Kisan Mela for the first time, while number of visit by the respondents varied from 1 to 10 . Visitors of Kisan Mela told that family obligation was one of the major constraints in attending these type of events (Pratap et al., 2019). Only 1.67 per cent respondents visited Kisan Mela ten times which indicates Kisan Mela provide useful platform for number of information. Table 1 further revealed the purpose of Kisan Mela visit which was varied from person to 
person, most of the respondents visited Kisan Mela for the sake of entertainment, purchase of good quality seed, to see the animal exhibition and to know technique related to organic farming. Kisan Mela is a better platform for the farmers to select different crops seeds on the basis of seed characteristics like yield, irrigation-need, fertilizer-need, crop duration and taste of produce (Sinha et al., 2013). It indicates although there is huge investment in terms of money, man power and time in organisation of a Kisan Mela, yet it is capable to fulfil number of needs of farmers involved in agriculture and allied sector. Farmers visiting the exhibition were showing interest in Rabi crop seeds, agriculture equipment and new technologies (Daily Pioneer, 2013). Table 1 further indicated that respondents were got information in various area such as improved seed variety, agricultural technology, bank loan and different categories of animal's exhibition. The majority of respondents said that they were not capable to pay for obtaining information regarding agriculture production system.

\section{Level of satisfaction}

Evaluation of farmers' satisfaction is very important for number of reasons such as the farmers is the ultimate beneficiaries of the farmers fair so they are the right persons to judge its performance, their personal experience about the Mela and their satisfaction level tells the future plan to continue the above type of activity (Elias et al., 2015). Table 2 revealed that majority of respondents $(69.2 \%)$ most satisfied with location of Kisan Mela venue whereas 21.7 per cent satisfied and 9.2 per cent respondents not satisfied with location of venue. On the basis of total weighed mean score, location of venue got $\mathrm{VI}^{\text {th }}$ rank in overall satisfaction criteria. In Kisan Mela participants came from different places of nation, so they consider various factors in regards of venue. Otherwise this venue is situated in the heart of most fertile land in western Uttar Pradesh. The table further revealed that 71.7 per cent respondents were most satisfied and 10.8 per cent not satisfied with orientation of different stall in Kisan Mela ground. In the Kisan Mela available space is utilized in best possible manner which gave beautiful look to Kisan Mela and ranked $\mathrm{V}^{\text {th }}$ on total weighed mean score. Drinking water facility is good at Mela ground, so 75.0 per cent respondents were most satisfied with that arrangement only very few respondents dissatisfied with drinking water arrangement.

The 85.0 per cent respondents were satisfied with staying facilities for livestock. Only 15.0 per cent respondents were not satisfied with staying facilities for livestock, this is might be due to their high value of animal in terms of money and affection. These were those respondents who participated in animal exhibition and staying facilities for livestock ranked $9^{\text {th }}$ on total weighed mean score. The animal exhibition is an important event of Kisan Mela for its success, so there is further need to improve staying facilities for livestock. The results also showed that 65.0 per cent of the respondents were most satisfied, 25.0 per cent satisfied and 10.0 per cent not satisfied with arrangement of animal exhibition. Animal exhibition mainly concerned with large animal in different categories, the judging committee comprised of senior scientist of reputed institute of the nation. The university officers were engaged in each and every steps of judging process, so that whole animal exhibition event might be completed in peaceful environment. Table 1 further revealed that 59.2 per cent of the respondents were most satisfied, 33.3 percent satisfied and 7.7 per cent respondents were not satisfied with availability of quality seeds in Kisan Mela which comes under $8^{\text {th }}$ rank in overall satisfaction level. 
Table.1 Profile of the respondents

\begin{tabular}{|c|c|c|c|}
\hline \multirow{2}{*}{ A } & \multicolumn{3}{|c|}{ Education of respondents } \\
\hline & Level of Education & Frequency & Percent \\
\hline 1 & Read and write & 08 & 6.67 \\
\hline 2 & Primary & 18 & 15.00 \\
\hline 3 & Junior/High School & 21 & 17.50 \\
\hline 4 & Intermediate & 34 & 28.33 \\
\hline 5 & Graduate and above & 39 & 32.50 \\
\hline B & \multicolumn{3}{|c|}{ Occupation of the respondents } \\
\hline 1 & Animal Husbandry (A.H.) & 15 & 12.50 \\
\hline 2 & Agriculture and A.H. & 54 & 45.00 \\
\hline 3 & Agriculture, A.H. and business & 44 & 36.67 \\
\hline 4 & Labour and A.H. & 07 & 5.83 \\
\hline $\mathbf{C}$ & \multicolumn{3}{|c|}{ Help of agency for visiting Kisan Mela } \\
\hline 1 & Self & 72 & 60.00 \\
\hline 2 & KVK & 44 & 36.67 \\
\hline 3 & NGO & 04 & 3.33 \\
\hline D & \multicolumn{3}{|c|}{ Number of Kisan Mela attended } \\
\hline 1 & 1 & 73 & 60.83 \\
\hline 2 & 2 & 11 & 9.17 \\
\hline 3 & 3 & 08 & 6.67 \\
\hline 4 & 4 & 06 & 5.00 \\
\hline 5 & 5 & 13 & 10.83 \\
\hline 6 & 6 & 07 & 5.83 \\
\hline 7 & 10 & 02 & 1.67 \\
\hline $\mathbf{E}$ & \multicolumn{3}{|c|}{ Purpose to visit Kisan Mela } \\
\hline 1 & For purchase of good quality seed & 21 & 17.50 \\
\hline 2 & To see new technology & 09 & 7.50 \\
\hline 3 & For the sake of entertainment & 19 & 15.83 \\
\hline 4 & $\begin{array}{c}\text { For the sake of entertainment, animal breeds and } \\
\text { seed purchase }\end{array}$ & 69 & 57.50 \\
\hline 5 & Information on organic farming & 02 & 1.67 \\
\hline $\mathbf{F}$ & \multicolumn{3}{|c|}{ Type of information obtained by respondents } \\
\hline 1 & Improved seed variety & 19 & 15.83 \\
\hline 2 & Animal exhibition & 61 & 50.83 \\
\hline 3 & Agricultural technology & 14 & 11.67 \\
\hline 4 & Improved seed variety and agriculture technology & 20 & 16.67 \\
\hline 5 & Bank loan & 6 & 5.00 \\
\hline G & \multicolumn{3}{|c|}{ Information need priority } \\
\hline 1 & Improved seed variety & 49 & 40.83 \\
\hline 2 & Agriculture technology & 38 & 31.67 \\
\hline 3 & Animal exhibition & 10 & 8.33 \\
\hline 4 & Animal disease control and pesticide & 17 & 14.17 \\
\hline 5 & Organic farming & 6 & 5.00 \\
\hline $\mathbf{H}$ & \multicolumn{3}{|c|}{ Capability to pay for information } \\
\hline 1 & Yes & 41 & 34.17 \\
\hline 2 & No & 79 & 65.83 \\
\hline
\end{tabular}


Table.2 Satisfaction of respondents in Kisan Mela

\begin{tabular}{|c|c|c|c|c|c|c|c|}
\hline $\begin{array}{l}\text { Sl. } \\
\text { No }\end{array}$ & Area of Satisfaction & $\begin{array}{c}\text { Most } \\
\text { Satisfied }\end{array}$ & Satisfied & $\begin{array}{c}\text { Not } \\
\text { satisfied }\end{array}$ & TS & TWMS & Rank \\
\hline 1 & Location of venue & $\begin{array}{c}83 \\
(69.17)\end{array}$ & $\begin{array}{c}26 \\
(21.67)\end{array}$ & $\begin{array}{c}11 \\
(9.16)\end{array}$ & 312 & 2.60 & VI \\
\hline 2 & $\begin{array}{l}\text { Orientation of different } \\
\text { stall }\end{array}$ & $\begin{array}{c}86 \\
(71.67)\end{array}$ & $\begin{array}{c}21 \\
(17.50)\end{array}$ & $\begin{array}{c}13 \\
(10.83)\end{array}$ & 313 & 2.61 & V \\
\hline 3 & $\begin{array}{l}\text { Drinking water } \\
\text { arrangement }\end{array}$ & $\begin{array}{c}90 \\
(75.00)\end{array}$ & $\begin{array}{c}27 \\
(22.50)\end{array}$ & $\begin{array}{c}3 \\
(2.50)\end{array}$ & 327 & 2.73 & III \\
\hline 4 & $\begin{array}{l}\text { Staying facilities for } \\
\text { livestock }\end{array}$ & $\begin{array}{c}75 \\
(62.50)\end{array}$ & $\begin{array}{c}27 \\
(22.50)\end{array}$ & $\begin{array}{c}18 \\
(15.00)\end{array}$ & 297 & 2.48 & VIX \\
\hline 5 & $\begin{array}{l}\text { Arrangement of animal } \\
\text { exhibition }\end{array}$ & $\begin{array}{c}78 \\
(65.00)\end{array}$ & $\begin{array}{c}30 \\
(25.00)\end{array}$ & $\begin{array}{c}12 \\
(10.00)\end{array}$ & 306 & 2.55 & VII \\
\hline 6 & $\begin{array}{l}\text { Availability of quality } \\
\text { seeds }\end{array}$ & $\begin{array}{c}71 \\
(59.17)\end{array}$ & $\begin{array}{c}40 \\
(33.33)\end{array}$ & $\begin{array}{c}9 \\
(7.50)\end{array}$ & 302 & 2.52 & VIII \\
\hline 7 & $\begin{array}{l}\text { Information regarding } \\
\text { new strains of crops }\end{array}$ & $\begin{array}{c}65 \\
(54.17)\end{array}$ & $\begin{array}{c}45 \\
(37.50)\end{array}$ & $\begin{array}{c}10 \\
(8.33)\end{array}$ & 295 & 2.46 & $X$ \\
\hline 8 & $\begin{array}{l}\text { Information regarding to } \\
\text { pesticide and insecticide }\end{array}$ & $\begin{array}{c}92 \\
(76.67)\end{array}$ & $\begin{array}{c}25 \\
(20.83)\end{array}$ & $\begin{array}{c}3 \\
(2.50)\end{array}$ & 329 & 2.74 & II \\
\hline 9 & $\begin{array}{l}\text { Information regarding } \\
\text { working condition of } \\
\text { animal hospital at } \\
\text { SVPUAT }\end{array}$ & $\begin{array}{c}57 \\
(47.50)\end{array}$ & $\begin{array}{c}43 \\
(35.83)\end{array}$ & $\begin{array}{c}20 \\
(16.67)\end{array}$ & 277 & 2.31 & XII \\
\hline 10 & $\begin{array}{l}\text { Information regarding } \\
\text { new technology } \\
\text { development in } \\
\text { agriculture }\end{array}$ & $\begin{array}{c}71 \\
(59.17)\end{array}$ & $\begin{array}{c}28 \\
(23.33)\end{array}$ & $\begin{array}{c}21 \\
(17.50)\end{array}$ & 290 & 2.42 & XI \\
\hline 11 & $\begin{array}{l}\text { Behaviour of different } \\
\text { Mela organizing persons } \\
\text { towards you }\end{array}$ & $\begin{array}{c}87 \\
(72.50)\end{array}$ & $\begin{array}{c}32 \\
(26.67)\end{array}$ & $\begin{array}{c}1 \\
(0.83)\end{array}$ & 326 & 2.72 & IV \\
\hline 12 & $\begin{array}{l}\text { Overall effect of Kisan } \\
\text { Mela }\end{array}$ & $\begin{array}{c}93 \\
(77.50)\end{array}$ & $\begin{array}{c}25 \\
(20.83)\end{array}$ & $\begin{array}{c}2 \\
(1.67)\end{array}$ & 331 & 2.76 & I \\
\hline
\end{tabular}

Data given in parenthesis indicates percentage

*TS $=$ Total Score, TWMS**= Total Weighted Mean Score

The above satisfaction pattern might be due to diversified need of the farmers about quality and variety of seeds. About 92.0 per cent of the respondents showed satisfaction level in the area of information regarding new strains of crops and only 8.3 per cent of the respondents were not satisfied. Similar trends were found in Punjab Agriculture University farmers' fare where farmers might be participated in the Kisan Mela to learn about newly developed crop varieties, their production and protection technologies in order to get maximum benefit in terms of productivity and profitability (Times of India, 2019).

Most of the respondents (76.7\%) showed most satisfaction in the area of information of pesticide and insecticide followed by 20.8 per cent showed satisfaction and only 2.5 per cent 
respondents were not satisfied with above area of satisfaction. In recent years, different insects and pests were harming the variety of crops at different stages of crop cultivation. Table 2 further revealed that 47.5 per cent respondents showed most satisfaction level regarding information of working animal hospital at SVPUAT, followed by satisfied $(38.8 \%)$ and 16.7 per cent were not satisfied with information regarding working of animal hospital. The animal hospital (Veterinary Clinical Complex) recently came into working condition and respondents belong to number of districts, so it takes time to become popular among public. Besides this, some steps may be taken such advertisement and distribution of pamphlet regarding quality and facilities at Veterinary Clinical Complex. Nearly 60 per cent respondents were most satisfied with information regarding new technology development in agriculture, this happen due to era of information which is spread very fast in Indian society. Only 23.3 per cent respondents were satisfied and with information regarding new technology developed in agriculture whereas 17.2 per cent respondents not satisfied. Most of the $(72.5 \%)$ respondents were most satisfied with behaviour of different Mela organizing persons towards them, followed by satisfied (26.7\%) and less than one per cent respondents unsatisfied with behaviour of organizing persons. Nearly all the respondents $(98.3 \%)$ were satisfied with overall effect of Kisan Mela, whereas very few persons $(1.7 \%)$ unsatisfied with overall effect of Kisan Mela. Evaluation of client satisfaction level can address the reliability and responsiveness of services or the willingness of providers to meet clients' needs (WHO, 2000).

The satisfaction level of respondents regarding location of venue, orientation of different stall, drinking water arrangement, staying facilities for livestock, arrangement of animal exhibition, availability of quality seeds, information regarding new strains of crops, information regarding to pesticide and insecticide and overall effect of Kisan Mela was very high.

The respondents visited Kisan Mela with different purposes which fulfilled on the same platform. These fairs cater the needs of young, adult and old, women, men or youth. Interactive sessions among scientist and farmers helped both in understanding the conditions on the field and test the applicability of the knowledge. Also, these fairs help farmers enhance their knowledge on new schemes or programs. Such fairs often attract an umpteen number of farmers, scientists, students, and extension personnel from the KVKs and the agriculture and allied departments (Tanusha and Chander, 2019).

\section{Acknowledgement}

Thanks to Sardar Vallabhbhai Patel University of Agriculture and Technology (SVPUAT), Meerut (U.P.), Dean, College of Veterinary and Animal Science, Director Research, SVPUAT and Director Extension, SVPUAT for providing information and necessary facilities during data collection.

\section{References}

Daily

Pioneer, 2013. http://dailypioneer.com/2013/stateeditions/all-india-kisan-mela-attractsfarmers-visitors-in-droves retrieve on 14/09/2019.

Dubey, A. K., Srivastava, J. P., Singh, R. P., Sharma, V. K. 2008. Impact of KVK training programme on socioeconomic status and knowledge of trainees in Allahabad district. Indian Res. J Ext. Edu. 8(283): 60-61.

Patel, M.M., Sharma, H.O. and Dubey, M.C. (1993). Communication source utilization pattern amongst the farmers. 
Maharastra Journal of Extension Education, 12,85.

Pratap J., Khan M.A., Singh V., Singh V.P. and Mandil R. 2019. Farmers' perception about constraints during Kisan Mela. The Pharma Innovation Journal; 8(9): 241-243.

Sharma A. K. 2014. Farmer's Satisfaction with Information Sources and Services: A Study on Farmer's Opinion, International Journal of Information Research, Vol 3 No 4 pp346-359.

Shirur, M. 2014. Regional Mushroom Mela and Kisan Goshthi: Enabling farmers To Access Technology and Advisory Services Proceedings of the 8th International Conference on Mushroom Biology and Mushroom Products (ICMBMP8).

Sinha, M. K., Nanda, P., Kumar, A., and Sahoo, N. R. 2013. Socio-Economic and Resource Profile Analysis of
Sogar Study Village. Research Bulletin No. 61, Directorate of Water Management (Indian Council of Agricultural Research), Chandrasekharpur, Bhubaneswar751023 Orissa pp-17.

Tanusha and Mahesh Chander, 2019. Farmers' fairs: can we make them impactful? The Road Ahead, Taking Stock and Shaping. The Future: Conversations on Extension, Agricultural Extension in South Asia (AESA), 212-215.

Times of India, 2019. https://timesofindia.indiatimes.com/cit y/ludhiana/2-day-kisan-mela-toeducate-farmers-on-agroprocessing/articleshow retrieve on 14/09/2019.

World Health Organization. 2000. Client Satisfaction Evaluation. Work Book 6. WHO, Geneva.

\section{How to cite this article:}

Jitendra Pratap Mohd. Ameer Khan, Rajesh Mandil, Vijay Singh and Singh, V.P. 2019. Level of Satisfaction among Farmers Attending Kisan Mela. Int.J.Curr.Microbiol.App.Sci. 8(11): 227-234. doi: https://doi.org/10.20546/ijcmas.2019.811.028 